\title{
Parliament debates junk food ads, vaping
}

\author{
Cite as: CMAJ 2018 April 3;190:E406-7. doi: 10.1503/cmaj.109-5584
}

Posted on cmajnews.com on Mar.13, 2018; revised Mar. 22, 2018

everal major health bills were nearing final reading in the House when Parliament returned from March break. The standing committee on health is discussing vaping regulations, tobacco plain-packaging rules, an act to strengthen drinking water guidelines and amendments to a ban on marketing junk food to children. The Senate is considering the cannabis act, a federal framework on post-traumatic stress disorder, and criminal offences for organ trafficking.

\section{Bill S-228, the child health protection act}

This Senate bill to prohibit the marketing of unhealthy food and beverages to children passed second reading in the House with support from Liberal and New Demo- crat members and is now before the standing committee on health.

Liberal MP and committee member Doug Eyolfson recommended amendments to change the definition of "children" from under age 17 to under age 13 . "It has become increasingly obvious that any regime built on restrictions aimed at older teenagers would be subject to considerable legal risks," he said.

Noting that industry has historically shifted marketing efforts to teenagers when restrictions are imposed on advertising to younger children, Eyolfson also recommended that Parliament conduct a mandatory review of the legislation, with a focus on the definition of children, within five years of the act coming into force.

Conservative MP and committee

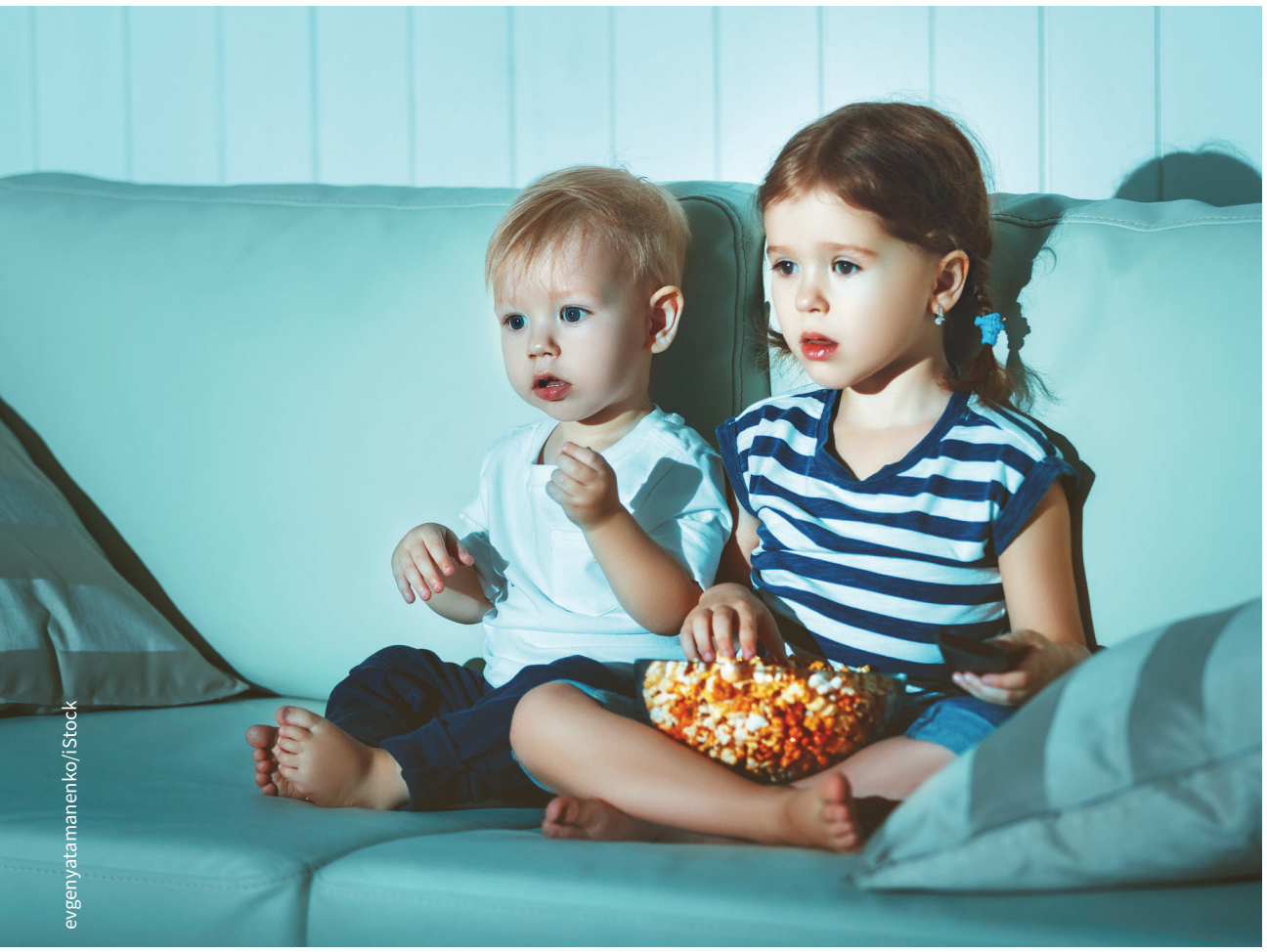

Bills on junk food marketing to children, plain packaging for tobacco, and legal cannabis are before the House and Senate. member Marilyn Gladu wants the bill scrapped. "Quebec has had this implemented for 40 years, and it had had no effect on the obesity rates," she claimed.

\section{Bill S-5, vaping regulations and} tobacco plain packaging rules Conservative members are pushing back on proposed advertising restrictions for vaping products and plain-packaging requirements for tobacco products under Bill S-5. At second reading in the House, Gladu argued there should be more leeway to advertise the harm-reduction benefits of vaping products, and claimed plain packaging would encourage contraband trade. "If a cigarette has absolutely no markings on it, we have no idea if it was made by a well-regulated industry or if it was made in someone's barn." Attempts to amend these aspects of the bill were defeated at committee. The standing committee on health also carried amendments to eliminate "lifestyle" advertising of vaping products and to allow Health Canada to require health warnings on cigarettes and other tobacco products.

\section{Bill C-326, an act to amend drinking water guidelines}

This Liberal private-member's bill would require the government to report annually on how Canada's drinking-water standards compare to those of peer nations in the Organisation for Economic Cooperation and Development. A 2006 report found that $75 \%$ of Canada's guidelines on acceptable limits for contaminants are weaker than those of at least one peer nation. "What is more, drinking water standards are not consistent across the country," said the bill's sponsor, Francis Scarpaleggi. The bill passed second reading with support from members of the three major parties. However, Conservative 
members raised concern that some international guidelines are not based on science, and implementation will still fall to the provinces and territories.

\section{Bill C-45, the cannabis act}

The Liberal government's bill to legalize marijuana passed the House and is now at second reading in the Senate. Conservative and independent senators raised concern about the limited time for public education about the harms of marijuana before the bill comes into force. "It is baffling that the experts who are asking for a moderate request to have more time for public education are being ignored by the government," said Conservative Senator Rose-May Poirier. She also argued that allowing Canadians to grow cannabis at home and setting the minimum age to buy pot at 18 puts young people at risk.

Independent senators appointed by Prime Minister Justin Trudeau echoed these concerns. "I can't shake the feeling that we are taking a big leap of faith, with a lot of unknowns and some serious risks ahead of us," said Senator Chantal Petitclerc. "While our government says that Bill C-45 aims for public health and harm reduction, it does not seem to listen to its own medical community by protecting youth properly until 25 years of age." Senator Frances Lankin suggested these concerns might be addressed by requiring a federal-provincial strategy on youth mental health "and resources for treatment and research focused on that."

\section{Bill C-211, the federal framework on} post-traumatic stress disorder act

Some senators are pushing to expand the scope of a proposed federal framework for the timely recognition, diagnosis, and treatment of post-traumatic stress disorder (PTSD). The Conservative private member's bill, which passed the House with unanimous support, focuses on improving services for first responders and military personnel. However, Independent Senator Wanda Thomas Bernard argued the bill should be more inclusive of other Canadians with PTSD, especially those who have experienced racism and gendered violence. She also recommended including doctors, nurses and social workers among the first responders given special consideration under the framework. Senators will debate specific amendments when the bill passes from second reading to committee.

\section{Bill S-240, sanctions on organ trafficking}

Conservative Senator Salma Ataullahjan championed this bill, which would create criminal offences for trafficking human organs and tissue, and deny admission to Canada to people suspected of engaging in such activities. Ataullahjan noted that Canadians have been documented but not prosecuted for buying black-market organs in foreign countries. These organs are often taken by coercion or force from "the poor, the indigent, the vulnerable and the marginalized," she said. "The recipients are wealthy, influential citizens from foreign countries, largely Western countries, who should be held criminally responsible." Canadians who travel abroad for illegal organs do so "almost exclusively" in order to save money on private transplants, Ataullahjan added. "The average price paid by a recipient for a kidney transplant is US $\$ 150000$, while the average price paid, if any, to a kidney victim donor is US\$5000."

Lauren Vogel, CMAJ 